\title{
SOCIOECONOMIC FACTORS AFFECTING AWARENESS AND ADAPTION OF CLIMATE CHANGE: A CASE STUDY OF BANKE DISTRICT NEPAL
}

\author{
Anish Shrestha*, Samata Baral \\ Agriculture and Forestry University, Rampur, Chitwan, Nepal \\ *Corresponding author's email: anishshrestha474@gmail.com
}

This is an open access article distributed under the Creative Commons Attribution License, which permits unrestricted use, distribution, and reproduction in any medium, provided the original work is properly cited.

\section{ARTICLE DETAILS}

\section{Article History:}

Received 26 June 2018 Accepted 2 July 2018

Available online 1 August 2018

\section{ABSTRACT}

\begin{abstract}
This study was carried to understand socioeconomic factors affecting knowledge and adaption of climate change among farmers of Banke district, with the hope that knowledge about climate change and their adaption strategy can be targeted properly among farmers and their empowerment can be achieved. All the farmers from Bageshwori Village Development committee were the target population for this study. Ninety households were selected as sampling respondents for this study. The study showed that $42.22 \%$ of the respondents know about climate change. The study revealed that $35 \%$ of the respondents know about climate change through self-experiences by comparing the past and present events of climatic parameters. Local radio and social organization were the main source of their knowledge about climate change, covering share of $27 \%$ and $23 \%$ of the respondents' means of knowledge. Age, gender and education of household head, contact to the extension workers, farming experience, presence of NGO/INGO and access to mass media found to be determinants of awareness of climate change with positive effect, except for household head age. Gender of household head, total annual income of family, farming experience, access to mass media, education of household head, farm size, presence of NGO/INGO and contact to extension workers were found to be determinants of climate change adoption. No decision is taken in vacuum, peoples' surrounding, and experience surely affects. So, to move forward and achieve climate smart agriculture these socioeconomic factors should be accounted while planning and implementation of program, project or policies.
\end{abstract}

\section{KEYWORDS}

Awareness, Adaption, Climate change, Socioeconomic factor.

\section{INTRODUCTION}

Earth's climate tends to change over the time, may it be due to natural causes or by human activities. With ever increasing population and never meeting demands of such large population, unsustainable use of resources is increasing rapidly. In addition, unsupervised industrialization and development of infrastructure are leading to deterioration of environment enforcing climate change [1]. Generally, Climate change is the accumulated status statistical distribution of the weather pattern which extends over very long period of time. It can be simply referred as the change in average weather condition. Climate change is becoming greater threat to sustainability of agricultural production. It is also threatening agriculture dependent livelihood and food security. The threat and vulnerability is catastrophic mainly to marginal and remote areas. It is one of the most complex challenges that humankind has to face in the coming decades [2]. Due to climate change, various sector of human life are affected. Effects are mainly seen in aspects such as agricultural sector, forestry, glacier, fresh water and biodiversity [3]. No person, no country, no place in the world is free from the challenges of climate change [1]. Nepal's temperature has increased by $1.7^{\circ} \mathrm{C}$ during last 30 years (1975 to 2005), and, the average temperature increased as $0.06^{\circ} \mathrm{C}$ per year and in particular, $0.04^{\circ} \mathrm{C}$ per year in plain area and $0.08^{\circ} \mathrm{C}$ per year in Himalayas [4].

Agriculture possesses an important part in the Nepalese economy as agriculture sector contribute $32.1 \%$ to National GDP and provides employment opportunity to $65.6 \%$ of total employed population [5]. Our agriculture practice is heavily dependent or influenced by weather. As agriculture-based nation our economy also is highly sensitive to the impact of climate change [6]. Despite negligible contribution to global greenhouse gas (GHG) emission, our country, Nepal is regarded as fourth vulnerable country from the perspective of climate change [7]. In the recent years, changes in weather pattern, temperature, humidity etc. has become more apparent. Climate change and its impacts are now clearly visible on ecosystem, human health, farmer's livelihoods, food security, water resources and tourism sector of Nepal [8]. Smallholder farmers, which include majority of Nepalese farmer, do not have adequate resources for effectively responding to the impacts of climate change, and are highly vulnerable to its negative consequences. This study was carried to understand socioeconomic factors affecting knowledge and adaption of climate change among farmers of Banke district, with the hope that knowledge about climate change and their adaption strategy can be targeted properly among farmers and their empowerment can be achieved.

\section{MATERIALS AND METHODS}

\subsection{Study Area}

This study was conducted in the Banke district, lying on western plain area of Nepal. The study focuses to explore the perception of smallholder farmers of Bageshwori VDC on climate change, its impact on agricultural crops and their adaptation strategies. 


\subsection{Sample Size, Sampling Procedure and Selection of the} Respondent

All the farmers from Bageshwori VDC were the target population for this study. During the selection of the respondent only age of above 30 years and at least 10 years of settlements within this locale were included in the sample, because they provide valuable and useful information regarding the past trends on climatic variables. Careful attention was paid to make the sample more inclusive as possible (i.e. inclusions of farmers from different wealth categories, different ethnic groups). Ninety households were selected as sampling respondents for this study.

\subsection{Source of Information}

For the primary data, pre-tested systematic semi structured questionnaire was used for face to face interview and key informant interview. Secondary information was mainly collected through reviewing different publications published by Ministry of Agriculture Development (MoAD), Department of Agriculture (DOA), Department of Hydrology and Meteorology (DHM), Central Bureau of Statistics (CBS), Nepalese Agriculture Research Council (NARC), District Agriculture Development Office. Other than those, published materials from different NGOs and INGOs, individual research and scholar research articles concerning climate change and its impact were considered.

\subsection{Survey Design and Data Collection}

For the collection of primary data two sets of interview schedule were prepared, one set to collect the information from farmers another set to collect the information from key informants [9]. Different variables were identified, and interview schedules were prepared accordingly. The field survey was conducted in January 2017. The respondents were interviewed using face to face method by visiting their homes. Key informants were interviewed in the same manner. Information obtained from the interview was crosschecked during the focus group discussion. Additional information on various community-based adaptation strategies, difference observed in the present and past regarding the farming practices was collected through focus group discussions.

\subsection{Data Analysis}

Primary data collected from the field survey and secondary data collected from other means were coded, tabulated and analyzed using Microsoft Excel. Qualitative data obtained during survey are studied and presented as tables or lists. And, obtained quantitative data are presented using simple descriptive statistics like frequency count, percentage, mean etc. Microsoft Excel and STATA 12 were used for data analysis.

\subsection{Socio-economic factors affecting latest technology adoption}

To estimate or analyze socioeconomic factor affecting technology adoption Logistic regression was used. Logistic regression is the appropriate regression analysis to conduct when the dependent variable is dichotomous (binary). Like all regression analyses, the logistic regression is a predictive analysis. Logistic regression is used to describe data and to explain the relationship between one dependent binary variable and one or more nominal, ordinal, interval or ratio-level independent variables. After key informant interview, focus group discussion and some reviewing, several socioeconomic factors such as education, gender and education of household head, occupation, participation in cooperatives and training etc. were used as independent variable to estimate their effect on knowledge and adoption to climate change.

The binary Logit regression model can be expressed as; $Y_{i}=f\left(\beta_{i} X_{i}\right)=f($ Age, Gender and Education of HH head, Occupation, Family size, Economically active family members, Training, Credit, Technical assistance, Cooperative, Farm size, farm area, Farming experience, Land type, Market distance etc.). Other details and value about variables are presented in Table 1.
Table 1: Description of the variables used in the Logit model

\begin{tabular}{|c|c|c|}
\hline Variables & Description & Value \\
\hline Age of $\mathrm{HH}$ & Age of household head & Number of Years \\
\hline Gender of HH & Gender of household head & $\begin{array}{l}\text { Female }=0, \\
\text { Male }=1\end{array}$ \\
\hline Education of $\mathrm{HH}$ & $\begin{array}{l}\text { Education of household } \\
\text { head }\end{array}$ & Number of Years \\
\hline Occupation & Major family occupation & $\begin{array}{l}\text { Other }=0, \\
\text { Agriculture }=1\end{array}$ \\
\hline Educated Number & $\begin{array}{l}\text { Educated member of the } \\
\text { family }\end{array}$ & Number \\
\hline $\begin{array}{l}\text { Economically } \\
\text { active members }\end{array}$ & $\begin{array}{l}\text { Number of (15-59) years } \\
\text { family members }\end{array}$ & Number \\
\hline Total size & Number of family members & Number \\
\hline Training & $\begin{array}{l}\text { Participation in farm related } \\
\text { training }\end{array}$ & $\mathrm{No}=0, \mathrm{Yes}=1$ \\
\hline Credit & Access to credit & $\mathrm{No}=0, \mathrm{Yes}=1$ \\
\hline Contact & $\begin{array}{l}\text { Contact with extension } \\
\text { workers }\end{array}$ & $\mathrm{No}=0, \mathrm{Yes}=1$ \\
\hline Cooperative & $\begin{array}{l}\text { Involvement in any } \\
\text { cooperatives }\end{array}$ & $\mathrm{No}=0, \mathrm{Yes}=1$ \\
\hline Farm size & Total owned land & Number of ha \\
\hline Income & Amount of income & $\begin{array}{ll}\text { Number } & \text { of } \\
\text { rupees }(, 000) & \end{array}$ \\
\hline $\begin{array}{l}\text { Farming } \\
\text { experience }\end{array}$ & $\begin{array}{l}\text { Years of involvement in rice } \\
\text { farming }\end{array}$ & Number of Years \\
\hline Land type & $\begin{array}{l}\text { Productivity of } \quad \text { rice } \\
\text { cultivating land }\end{array}$ & $\begin{array}{l}0=\text { less, } 1=\text { high } \\
\text { productivity }\end{array}$ \\
\hline $\begin{array}{l}\text { NGO/INGO } \\
\text { presence }\end{array}$ & $\begin{array}{l}\text { Presence of organizations } \\
\text { acting in the field of climate } \\
\text { change }\end{array}$ & $\mathrm{No}=0, \mathrm{Yes}=1$ \\
\hline Access to media & $\begin{array}{l}\text { Access to source of mass } \\
\text { communication such as } \\
\text { radio, TV, newspaper }\end{array}$ & $\mathrm{No}=0 . \mathrm{Yes}=1$ \\
\hline
\end{tabular}

\section{RESULT AND DISCUSSION}

\subsection{Study Area}

Banke district lies in the western plain part of Nepal which falls in Bheri Zone. The district covers an area of 2,337 $\mathrm{km}^{2}$ (225836 ha), among the total area $79.1 \%$ of area falls under lower tropics. The altitude of the district is $127 \mathrm{~m}$ to $1236 \mathrm{~m}$ from the mean sea level. Among the total area, $57,252(23.4 \%)$ ha of land is suitable for agriculture, among which 37838 ha is occupied by lowland and 15000 ha by upland [10]. There are 47 VDCs and 94,773 households in Banke comprising population of 491,313, in which males are 244255 (49.71\%) and females are 247,058 (50.29\%). It has average household size of 5.18 with sex ratio of 98.9 and population density of 210. There are total nine wards in Bageshwori VDC with the household number of 2840 and average household size of 4.49 .

Among total population within the study area (including family member of respondents), males comprised $45.3 \%$ and females comprised $54.7 \%$ of total population which is slight variation from the CBS data of the VDC comprising $44.2 \%$ males and $55.8 \%$ females [11]. 
Table 2. Determinants of climate change awareness.

The study showed that $42.22 \%$ of the respondents know about climate change, which is very low compared to similar study of Kenya i.e. $96.47 \%$ of population were aware about climate change [12]. Out of 38 respondents who were aware about climate change only $18.3 \%$ of them knew climate change clearly, $33.1 \%$ knew ambiguously and majority of respondents $48.6 \%$ of them knew climate change a little bit. The study revealed that $35 \%$ of the respondents know about climate change through their self-experiences by comparing the past and present events of climatic parameters such as change in temperature, rainfall pattern etc., $27 \%$ through media such as local FM, 23\% of the respondents said that they know about climate change through social organization working in that area, their relatives, neighbors and local leaders and only $15 \%$ of them got the information from extension agents which is very low compared to what reported in Adamawa State, Nigeria and shows dire need of extension agents to focus on this issue [13].

\subsection{Socioeconomic factors affecting knowledge of climate change}

Among eleven socioeconomic variables listed only seven variables found to be determinant of knowledge of climate change. Age of household head contact to the extension workers, and number of farming experience years found to be significant and $10 \%$ level, while gender of household head found to be significant at $5 \%$ level. Similarly, education level of household head, presence of NGO/INGO in the locality and access to means of mass communication found to be significant at $1 \%$ level.

Result showed that with increase in age of household head by 1 year can decrease the possibility of knowledge about climate change by $1.24 \%$. It was also found that education of household hold by 1 year can increase the possibility of awareness about climate change by $15.07 \%$. This result is similar to the outcome of research in Borno State, Nigeria, which reported that age of household head and education year of household head has significant effect on awareness of climate change with contribution of $0.54 \%$ and $15.17 \%$ respectively [14]. This result is also supported by the study carried in Abia State, Nigeria, as it states that education of household has positive and significant effect on awareness about climate [15].

Study also indicates that probability of awareness about climate change is $13.42 \%$ more in male headed household than female headed household. This finding is supported by study of Kenya, which states that awareness and knowledge about climate change is higher in male headed households than female headed households [16]. The study showed that contact with extension worker can increase the possibility of awareness about climate change by $13.29 \%$, which is similar to the finding of Borno State, Nigeria [14].

Result showed that increase in farming experience by a year can increase the possibility of awareness about climate change by $8.32 \%$. This result is supported by study of Odisha, India, which states that longer farming experience results in increasing awareness about climate change, due to their exposure to variation and pattern in weather with longer experience [17].

Result also showed that presence of NGO/INGO can increase the possibility of awareness about climate change by $36.41 \%$. Study of NGOs role in climate change suggests that efficiency and activities of NGOs are highly significant for the awareness and understanding of farmers and local communities about climate change [18].

Result also showed that access to mass media or source of mass communication can increase the possibility of awareness about climate change by $31.28 \%$. This result is supported by findings of Ireland, which states that farmer's lack of access to media and lack of familiarity to social media causes to limited source of information and lack of awareness about climate change [19]. Further details about determinants of climate change awareness are presented in Table 2 .

\begin{tabular}{|l|lllc|}
\hline Variables & dy/dx & Std. Err. & $\mathrm{p}>|\mathrm{z}|$ & \\
\hline Age HH & -0.0124 & 0.0063 & 0.051 & $*$ \\
Gender HH \# & 0.1342 & 0.1216 & 0.011 & $* *$ \\
Education HH & 0.1507 & 0.0196 & 0.001 & $* * *$ \\
Occupation \# & 0.2209 & 0.1607 & 0.169 & \\
Educated number & 0.1972 & 0.2138 & 0.132 & \\
Training \# & 0.0032 & 0.0121 & 0.683 & \\
Cooperative \# & 0.0128 & 0.0119 & 0.321 & \\
Contact \# & 0.1329 & 0.1154 & 0.059 & $*$ \\
Farming & 0.0832 & 0.1730 & 0.081 & $*$ \\
experience & & & & \\
NGO/INGO \# & 0.3641 & 0.1643 & 0.002 & $* * *$ \\
Media \# & 0.3128 & 0.1243 & 0.001 & $* * *$ \\
\hline
\end{tabular}

respectively.

(\#) dy/dx is for discrete change of dummy variable from 0 to 1 .

\subsection{Adoption strategy of the locality}

From the focus group discussion, key informant interview, general discussion and observation some of the major adoption strategy was identified. Most common adoption strategy was found to be cultivation of tolerant varieties. Different varieties of rice such as Sukha Rice -2, 3, Survi etc. drought tolerant verities and other high breed varieties were being cultivated in the locality. Change in planting time such as delay planting in the year of delayed monsoon or early planting in the year of early monsoon were other measure. To compensate lost yield or avoid the risk of single crop, mixed or intercropping were used in the locality. Other means of irrigation such pumps, borings etc. were implemented by farmers to avoid water scarcity. Early planting of wheat to avoid higher temperature during fruiting and flowering period were also noticed in the locality. Similar strategy of climate change adoption were observed in case of India [17].

\subsection{Socioeconomic factors climate change adoption strategy}

Among fifteen socioeconomic variables listed only eight variables found to be determinant of knowledge of climate change. Gender of household head, total annual income of family, number of farming experience years and access to means of mass communication found to be significant and $10 \%$ level, while education of household head, total farm size and presence of NGO/INGO in the locality found to be significant at $5 \%$ level. Similarly, contact to extension workers found to be significant at $1 \%$ level.

Study indicates that probability of adoption of climate change strategy is $8.78 \%$ more in male headed household than female headed household. This finding is supported by study of Abia State, Nigeria, which states that probability of adoption of climate change strategy is $10.30 \%$ more in male headed family than female headed [15]. Result also showed that increase in education by a year can increase the possibility of adoption of climate change strategy is increase by $14.04 \%$. This finding is supported by study of South Africa, which states that probability of adoption of climate change strategy is increased by $14.30 \%$ with increase in education year [20].

Result also showed that access or contact to extension worker can increase the possibility of adoption of climate change strategy is increase by $23.11 \%$. This finding is supported by study of Borno State, Nigeria, which states that probability of adoption of climate change strategy is increased with contact to extension worker [14]. Result also showed that increase in 
farm size increase the possibility of adoption of climate change strategy is increase by $3.52 \%$. This finding is supported by study of South Africa, which states that probability of adoption of climate change strategy is increased with increase in farm size [20].

Result also showed that increase in income can increase the possibility of adoption of climate change strategy is increase by $12.05 \%$. This finding is supported by study of Odisha, India, which states that probability of adoption of climate change strategy is increased with increase in annual income of household [17]. Result also showed that increase in farming experience can increase the possibility of adoption of climate change strategy is increase by $14.53 \%$. This finding is supported by study of Southeast, Nigeria, which states that probability of adoption of climate change strategy is increased with increase in farm size [21].

Result also showed that presence of NGO/INGO can increase the possibility of adoption of climate change strategy is increase by $28.31 \%$. Study of NGOs role in climate change suggests that efficiency and activities of NGOs are highly significant for the climate change adoption of farmers [18].

Result also showed that access to media or source of mass communication can increase the possibility of adoption of climate change strategy is increase by $11.32 \%$. This finding is supported by several outlets and publications which suggest that the way media presents the issues of climate change and means to their mitigation is highly affects the probability of climate change adoption of farmers [19]. Further details about determinants of climate change adoption are presented in Table 3.

Table 3. Determinants of climate change adoption.

\begin{tabular}{|c|c|c|c|c|}
\hline Variables & $\mathrm{dy} / \mathrm{dx}$ & Std. Err. & $\mathrm{p}>|\mathrm{z}|$ & \\
\hline Age $\mathrm{HH}$ & -0.0056 & 0.2838 & 0.834 & \\
\hline Gender HH \# & 0.0878 & 0.2451 & 0.083 & * \\
\hline Education $\mathrm{HH}$ & 0.1404 & 0.0706 & 0.032 & $* *$ \\
\hline Occupation \# & 0.1789 & 0.9244 & 0.854 & \\
\hline Educated number & 0.2143 & 0.1894 & 0.288 & \\
\hline $\begin{array}{l}\text { Economically } \\
\text { active }\end{array}$ & 0.0848 & 0.4180 & 0.194 & \\
\hline Total size & 0.0275 & 0.1443 & 0.849 & \\
\hline Credit \# & 0.2784 & 0.3257 & 0.389 & \\
\hline Cooperative \# & 0.4836 & 0.6834 & 0.856 & \\
\hline Contact \# & 0.2311 & 0.1923 & 0.002 & $* * *$ \\
\hline Farm size & 0.0352 & 0.0029 & 0.011 & $* *$ \\
\hline Income & 0.1205 & 0.0893 & 0.056 & $*$ \\
\hline $\begin{array}{l}\text { Farming } \\
\text { experience }\end{array}$ & 0.1453 & 0.2532 & 0.085 & * \\
\hline NGO/INGO \# & 0.2831 & 0.1936 & 0.043 & $* *$ \\
\hline Media \# & 0.1132 & 0.1231 & 0.019 & $* *$ \\
\hline
\end{tabular}

Note: ${ }^{* * *},{ }^{* *}$ and ${ }^{*}$ indicates $1 \%, 5 \%$ and $10 \%$ level of significance respectively.

(\#) dy/dx is for discrete change of dummy variable from 0 to 1 .

\section{CONCLUSION}

Climate change is one of the most complex challenges that humankind has to face in the coming decades and it has already started to show its face.
Climate change is not a new concept or new idea to anyone at this stage. As human civilization is moving forward, more and more we are moving on the direction of doomsday. Climate change is the result of our cynical and irresponsible acts. Impact of climate change has started to affect more and more people and more and more region of the world. The threat and vulnerability are catastrophic mainly to marginal and remote areas. No sector, person or region is free from impacts of climate change. Our agriculture sector is highly vulnerable to impact of climate change, as it is highly dependent on weather. Our agriculture has not been climate smart and nor so our policies regarding climate change. Few policies and action has been carried but that's not enough. This studies shows that still majority of farmers have no idea about what climate change is and how to combat it. This study and several other studies also show that there are several socioeconomic factors that affects awareness and adaption of climate change. No decision is taken in vacuum, peoples' surrounding, and experience surely affects. So, to move forward and achieve climate smart agriculture these socioeconomic factors should be accounted while planning and implementation of program, project or policies.

\section{REFERENCES}

[1] Kumar, V. 2014. Role of Indigenous Knowledge in Climate Change Adaptation Strategies: A Study with Special Reference to North-Western India. Journal of Geography and Naural Disaster, 5, 1-5.

[2] Regmi, B.R., Bhandari, D. 2013. Climate Change Adaption in Nepal. Journal of Forestry and Livelihood, 11, 43-61.

[3] Ebi, K.L., Corvalan, C., Hildebrand, A.V., Woodruff, R. 2007. Climate Change related Health Impacts in the Hindu Kush-Himalayas. EcoHealth Journal, 4, 264-270.

[4] Shrestha, A.B., Dibbl, J.E., Mayewski, P.A., Wake, C.P. 1999. Maximum temperature trends in the Himalaya and its vicinity. Journal of Climate, 12 , 2775-2787.

[5] Shrestha, A. 2018. Study of Production Economics and Production Problems of Honey in Bardiya District, Nepal. Sarhad Journal of Agriculture, 34 (2), 240-245.

[6] Alam, M., Regmi, B. 2004. Adverse Impact of Climate Change on Development of Nepal: Integrating Adaptation into Policies and Activities. Bangladesh Center for Advanced Studies, Dhaka, Bangladesh.

[7] JVS. 2015. Stocktaking: Climate Vulnerability on Agricultural Sector for National Adaption Plan Process.Jalsrot Vikas Sanstha, Kathmandu, Nepal.

[8] Karki, M., Mool, P., Shrestha, A. 2009. Climate Change and Its Increasing Impacts in Nepal. The Initiation: A Journal of Forestry Science, 3, 30-37.

[9] Shrestha, A., Sapkota, B., Regmi, R., Dhungana, S.M. 2018. Economics of Production and Marketing of Banana in Chitwan District, Nepal. Azarian Journal of Agriculture, 5 (1), 12-19.

[10] DADO. 2017. District Agriculture Data Book, Khajura, Banke. District Agriculture Development Office, Banke, Nepal.

[11] CBS. 2011. National Population Census 2011. Central Bureau of Statistics. National Planning Commission of Nepal, Kathmandu, Nepal.

[12] Adebayo, A.A., Onu, J.I., Adebayo, E.F., Anyanwu, S.O. 2012. Farmers' Awareness, Vulnerability and Adaptation to Climate Change in Adamawa State, Nigeria. British Journal of Arts and Social Science, 9, 104-115.

[13] Yohanna, I., Ndaghu, A.A., Barnabas, B.P. 2014. Sources of Information on Climate Change among Arable Crop Farmers, In Adamawa State, Nigeria. IOSR Journal of Agriculture and Veterinary Science, 7, 32-36. 
[14] Idrisa, Y.L., Ogunbameru, B.O., Ibrahim, A.A., Bawa, D.B. 2012. Analysis of Awareness and Adaptation to Climate Change among Farmers in the Sahel Savannah Agro-ecological Zone of Borno State, Nigeria. British Journal of Environment \& Climate Change, 2 (2), 216-222.

[15] Anyoha, N.O., Nnadi, F.N., Chikaire, J., Echetama, J.A., Utazi, C.O., Ihenacho, R.O. 2013. Socio-Economic Factors Influencing Climate Change Adaptation among Crop Farmers in Umuahia South Area of Abia State, Nigeria. Net Journal of Agricultural Science, 1 (2), 42-47.

[16] Opiyo, F., Wasonga O.V., Nyangito, M.M., Mureithi, S.M., Obando, J., Munang, R. 2016. Determinants of Perceptions of Climate Change and Adaptation among Turkana Pastoralists in Northwestern Kenya. Climate and Development, 8 (2), 179-189.

[17] Sahu, N.C., Mishra, D. 2013. Analysis of Perception and Adaptability Strategies of the Farmers to Climate Change in Odisha, India. APCBEE Procedia, 5, 123-127.
[18] Giorgetti, C. 1998. The Role of Nongovernmental Organizations in the Climate Change Negotiations. Journal of International Environmental Legislation and Policy, 9 (1), 115-137.

[19] Swain, K.A. 2012. Handbook of Climate Change Mitigation, First edition. Springer, New York, USA.

[20] Taruvinga, A., Visser, M., Zhou, L. 2016. Determinants of Rural Farmers' Adoption of Climate Change Adaptation Strategies: Evidence from the Amathole District Municipality, Eastern Cape Province, South Africa. International Journal of Environmental Science and Development, 7 (9), 687-692.

[21] Nwachukwu, I.A., Shisanya, C.A., Dasgupta, P., Mbanasor, J.A. 2015. Socioeconomic Response Patterns of Farmers to Climate Change in Africa: Lessons from Southeast Nigeria. Nigeria Agricultural Journal, 46 (1), 48-56.

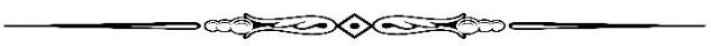

